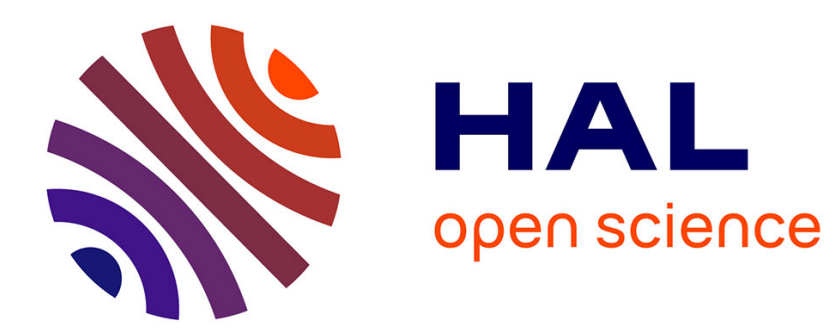

\title{
The Janus faces of bicarbonate therapy in the ICU
}

Boris Jung, Samir Jaber

\section{To cite this version:}

Boris Jung, Samir Jaber. The Janus faces of bicarbonate therapy in the ICU. Intensive Care Medicine, 2019, 46, pp.516-518. 10.1007/s00134-019-05835-3 . hal-02368516

\section{HAL Id: hal-02368516 https://hal.science/hal-02368516}

Submitted on 5 Jun 2020

HAL is a multi-disciplinary open access archive for the deposit and dissemination of scientific research documents, whether they are published or not. The documents may come from teaching and research institutions in France or abroad, or from public or private research centers.
L'archive ouverte pluridisciplinaire HAL, est destinée au dépôt et à la diffusion de documents scientifiques de niveau recherche, publiés ou non, émanant des établissements d'enseignement et de recherche français ou étrangers, des laboratoires publics ou privés. 


\title{
The Janus faces of bicarbonate therapy in the ICU
}

\author{
Boris Jung ${ }^{1,2}$ and Samir Jaber ${ }^{2,3^{*}}$
}

\section{State of the art}

Metabolic acidosis is characterized by a primary reduction in plasma bicarbonate concentration below $20 \mathrm{mmol} / \mathrm{L}$ in the Henderson-Hasselbalch method and with either an imbalance between strong plasma cations concentration compared to the strong anions concentration (decreasing thus the strong ion difference) and/or an excess in non-volatile weak acids in the Stewart-Fencl method $[1,2]$. Acidemia is the term used if the plasma $\mathrm{pH}$ is equal to or below 7.38, acidemia being described as severe when the $\mathrm{pH}$ is equal to or below $7.20[3,4]$. Metabolic acidemia can be associated with organ failure, in particular respiratory failure (increased ventilatory demand) and cardiovascular failure (arterial vasodilation, decreases in cardiac inotropism and cardiac output, ventricular arrhythmia) $[1,5,6]$. Metabolic acidemia is observed in $14-42 \%$ of the critically ill patients [7] and, when acidemia is severe $(\mathrm{pH}<7.20)$ and persists, is associated with $50-60 \%$ mortality in the Intensive Care Unit (ICU) $[7,8]$. The best treatment option to treat metabolic acidosis is the causal treatment which can be very different according to the disease. Facing metabolic acidemia, a short list of strong indications (gastrointestinal or urinary loss of bases, ethylene glycol, methanol and salicylate poisoning) and non-indications (diabetic ketoacidosis, tumor lysis syndrome) have been recommended [1, 3]. In other situations, such as lactic acidosis, in order to save time in view of the elimination of the underlying cause, one may suggest to administer intravenous sodium bicarbonate to counter balance the negative effects of acidemia

\footnotetext{
*Correspondence: s-jaber@chu-montpellier.fr

${ }^{3}$ Intensive Care Unit, Anesthesiology and Intensive Care, Anesthesia and Critical Care Department B, Saint Eloi Teaching Hospital, Centre Hospitalier Universitaire Montpellier, University Montpellier, 1, 80 Avenue Augustin Fliche, 34295 Montpellier Cedex 5, France

Full author information is available at the end of the article
}

on organ function. Although often performed [7, 9], this treatment has not to date been supported by the few prospective studies available $[10,11]$.

\section{Controversies}

The risk-benefit balance of sodium bicarbonate infusion to increase the plasma $\mathrm{pH}$ level has been challenged by the absence of high-quality prospective studies and the possible side effects of its infusion.

Sodium bicarbonate is indeed associated with a significant risk of hypokalemia, hypernatremia, volume overload, ionized hypocalcemia and metabolic alkalosis $[1,12]$. Uncertain adverse effects such as paradoxical intracellular acidosis secondary to the passive diffusion of carbon dioxide across the cellular membrane has also been reported in some in vitro experiments using different types of cells and buffer conditions [13], but has never been reported in humans [14]. The retention of carbon dioxide following rapid sodium bicarbonate infusion might also occur especially in spontaneous breathing patients with type II hypercapnic respiratory failure.

Acidosis is associated with a decreased hemoglobin affinity for oxygen (Bohr effect) and the rapid infusion of sodium bicarbonate might be associated with an increase in hemoglobin affinity for oxygen lowering the oxygen availability to the cells [15].

This side effect, illustrated by a mean drop in the central vein oxygen saturation of $4 \mathrm{mmHg}$ in one physiological study, appears to be transient [10].

Whether it is the bicarbonate or the sodium load that is associated with the plasma $\mathrm{pH}$ increase is another controversy. In the Henderson-Hasselbalch method, since $\mathrm{pH}=$ plasma $p \mathrm{Ka}+\log _{10}\left[\mathrm{HCO}_{3}{ }^{-}\right] / 0.03 \times\left[\mathrm{PaCO}_{2}\right]$ is the central equation, it is the load in $\mathrm{HCO}_{3}{ }^{-}$which is associated with the increase in the plasma $\mathrm{pH}$. The StewartFencl method claims that the independent parameter that regulates the $\mathrm{pH}$ is the difference between measured 
cations and anions (named strong ion difference) rather than plasma bicarbonate concentration [2]. According to the Stewart-Fencl method, sodium bicarbonate infusion would then increase the plasma $\mathrm{pH}$ level because of the massive sodium intake without chloride.

\section{Recent advances in knowledge}

We recently performed the first large multiple center randomised clinical trial in which 400 severe acidemic $(\mathrm{pH} \leq 7.20)$ critically ill patients were randomised to either intervention (4.2\% intravenous sodium bicarbonate) to target a $\mathrm{pH}$ equal or greater than 7.30 or control (no intravenous sodium bicarbonate) [12]. Three strata were preplanned (age with a cutoff of 65 years, sepsis and moderate to severe acute kidney injury). The primary endpoint was a composite score of mortality by day 28 and the presence of an organ failure (assessed by the SOFA score) at day 7. The Kaplan-Meier method estimate of the probability of survival at day 28 between the control group and bicarbonate group in the overall population was not significant (46\% [95\% CI 40-54] vs $55 \%$ [49-63]; $p=0.09$ ). However, after multivariate analysis, sodium bicarbonate infusion was associated with fewer deaths (crude HR 0.783, 95\% CI 0.0589-1.040; $p=0.091$; and adjusted HR 0.727, 95\% CI 0.540-0.979; $p=0.0356$ ). The number of days alive free from renal replacement therapy was significantly lower in the control group than in the bicarbonate group (8 (0-28) vs 19

\section{THE BICAR-ICU trial}

(Jaber et al, The Lancet 2018)

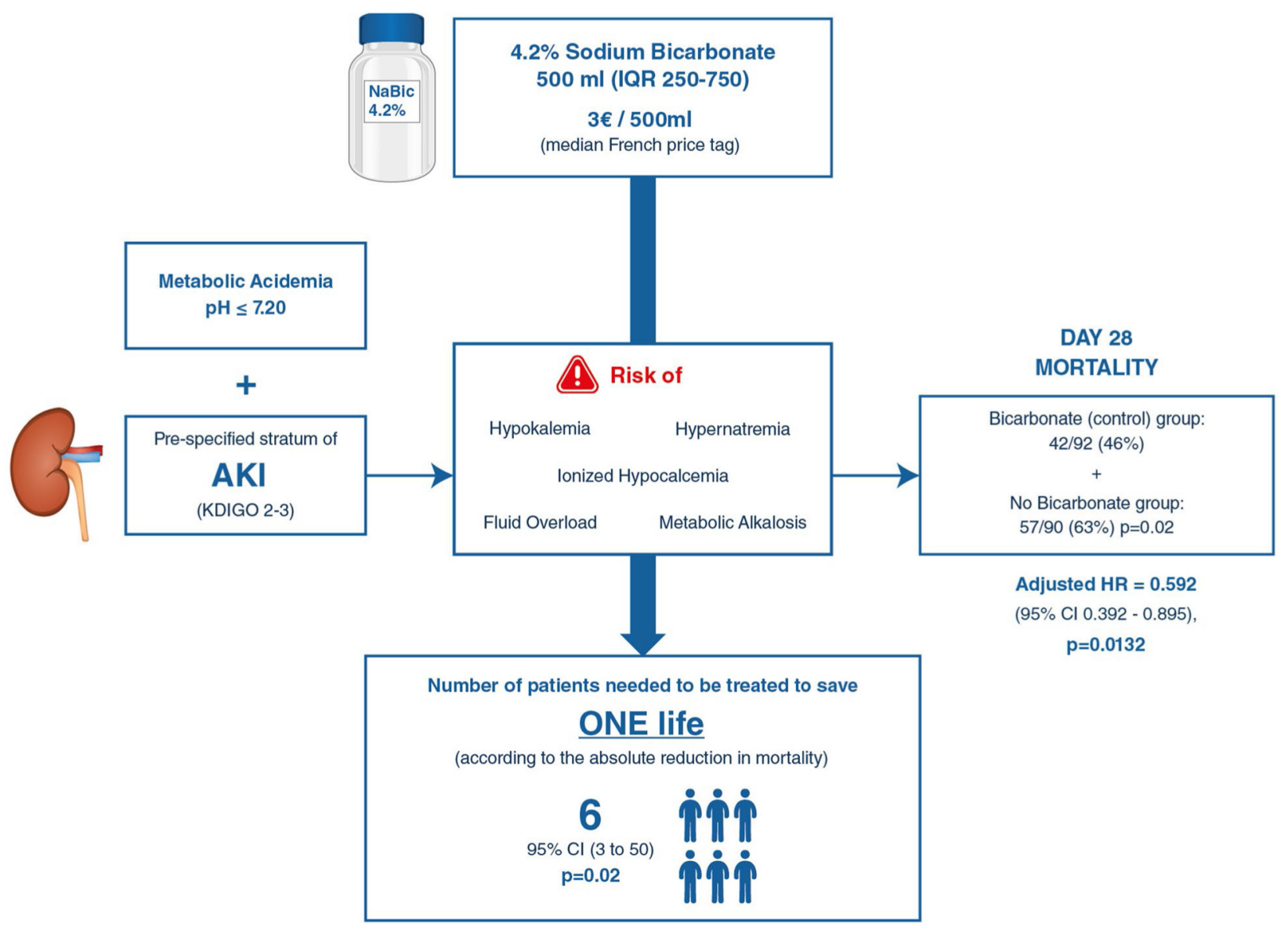

Fig. 1 Among the 400 critically ill patients with severe metabolic acidemia enrolled in the BICAR-ICU trial, 182 were enrolled in the moderate to severe acute kidney injury stratum and randomised to the $4.2 \%$ sodium bicarbonate group or to the no sodium bicarbonate (control) group [12]. The primary composite outcome as well as the day mortality was lower in the bicarbonate group than in the control group. After taking into consideration the absolute risk reduction of death, six patients ( $95 \%$ confidence interval 3 to 50 ) was the estimate number of patients needed to be treated to save one life by day 28 
(1-28), $p=0.015)$. In the prespecified stratum of patients with moderate or severe acute kidney injury, the KaplanMeier method estimate of survival by day 28 between the control group and bicarbonate group was significant (63\% [95\% CI 52-72] vs 46\% [35-55]; $p=0.0283)$. According to this result, the number of patients needed to be treated to save one life by day 28 was 6 (95\% CI 3-50, $p=0.02$ ). Whether it is the sodium bicarbonate infusion or the delay to start the renal replacement therapy that was associated with a decrease in mortality in the stratum of acute kidney injury group is, however, unclear and might investigated in future studies, as suggested [16]. Metabolic alkalosis, hypernatremia, and hypocalcemia were observed more frequently in the bicarbonate group than in the control group, with no life-threatening complications reported. In a retrospective analysis of a large US-database, Zhang et al. confirmed these results showing that survival was improved only in patients presenting sepsis and moderate to severe acute kidney injury and severe acidemia $(\mathrm{pH}<7.20)[17]$.

\section{Research agenda}

The BICARICU trial did not show an effect on the primary composite endpoint of an intravenous sodium bicarbonate infusion in the overall population, but suggests a benefit for patients with kidney injury [12] (Fig. 1). The BICARICU-2 multiple center randomised trial will start in France in 2019 and will explore the impact of sodium bicarbonate infusion in moderate to severe acute kidney injury with severe acidemia critically ill patients. Other questions remain unresolved in 2019. Indeed, 1: the comparison between renal replacement therapy vs sodium bicarbonate infusion on severely academic patients outcome and 2: the plasma $\mathrm{pH}$ target in interventional trials have never been examined.

\section{Author details}

1 Département de Médecine Intensive et Réanimation, CHU Montpellier, 34000 Montpellier, France. ${ }^{2}$ PhyMedExp, INSERM U1046, CNRS, UMR 9214, Centre Hospitalier Universitaire Montpellier, University of Montpellier, 34295 Montpellier Cedex 5, France. ${ }^{3}$ Intensive Care Unit, Anesthesiology and Intensive Care, Anesthesia and Critical Care Department B, Saint Eloi Teaching Hospital, Centre Hospitalier Universitaire Montpellier, University Montpellier, 1, 80 Avenue Augustin Fliche, 34295 Montpellier Cedex 5, France.

\section{Compliance with ethical standards}

\section{Conflicts of interest}

Pr. Jaber reports receiving consulting fees from Drager, Fisher \& Paykel and Fresenius.

\section{References}

1. Kraut JA, Madias NE (2012) Treatment of acute metabolic acidosis: a pathophysiologic approach. Nat Rev Nephrol 8:589-601. https://doi. org/10.1038/nrneph.2012.186

2. Fencl V, Jabor A, Kazda A, Figge J (2000) Diagnosis of metabolic acidbase disturbances in critically ill patients. Am J Respir Crit Care Med 162:2246-2251

3. Jung B, Martinez M, Claessens Y-E et al (2019) Diagnosis and management of metabolic acidosis: guidelines from a French expert panel. Ann Intensive Care 9(1):92. https://doi.org/10.1186/s13613-019-0563-2

4. Kraut JA, Madias NE (2014) Lactic acidosis. N Engl J Med 371:2309-2319. https://doi.org/10.1056/NEJMra1309483

5. Kimmoun A, Novy E, Auchet T et al (2015) Hemodynamic consequences of severe lactic acidosis in shock states: from bench to bedside. Crit Care Lond Engl 19:175. https://doi.org/10.1186/s13054-015-0896-7

6. Kraut JA, Madias NE (2010) Metabolic acidosis: pathophysiology, diagnosis and management. Nat Rev Nephrol 6:274-285. https://doi. org/10.1038/nrneph.2010.33

7. Jung B, Rimmele T, Le Goff C et al (2011) Severe metabolic or mixed acidemia on intensive care unit admission: incidence, prognosis and administration of buffer therapy. A prospective, multiple-center study. Crit Care 15:R238. https://doi.org/10.1186/cc10487

8. Smith I, Kumar P, Molloy S et al (2001) Base excess and lactate as prognostic indicators for patients admitted to intensive care. Intensive Care Med 27:74-83

9. Kraut JA, Kurtz I (2006) Use of base in the treatment of acute severe organic acidosis by nephrologists and critical care physicians: results of an online survey. Clin Exp Nephrol 10:111-117. https://doi.org/10.1007/ s10157-006-0408-9

10. Mathieu D, Neviere R, Billard V et al (1991) Effects of bicarbonate therapy on hemodynamics and tissue oxygenation in patients with lactic acidosis: a prospective, controlled clinical study. Crit Care Med 19:1352-1356

11. Cooper DJ, Walley KR, Wiggs BR, Russell JA (1990) Bicarbonate does not improve hemodynamics in critically ill patients who have lactic acidosis. A prospective, controlled clinical study. Ann Intern Med 112:492-498

12. Jaber S, Paugam C, Futier E et al (2018) Sodium bicarbonate therapy for patients with severe metabolic acidaemia in the intensive care unit (BICAR-ICU): a multicentre, open-label, randomised controlled, phase 3 trial. Lancet 392:31-40. https://doi.org/10.1016/S0140-6736(18)31080-8

13. Levraut J, Giunti C, Ciebiera J-P et al (2001) Initial effect of sodium bicarbonate on intracellular $\mathrm{pH}$ depends on the extracellular nonbicarbonate buffering capacity. Crit Care Med 29:1033-1039. https://doi. org/10.1097/00003246-200105000-00032

14. Nielsen HB, Hein L, Svendsen LB et al (2002) Bicarbonate attenuates intracellular acidosis. Acta Anaesthesiol Scand 46:579-584

15. Bellingham AJ, Detter $J C$, Lenfant C (1971) Regulatory mechanisms of hemoglobin oxygen affinity in acidosis and alkalosis. J Clin Invest 50:700-706. https://doi.org/10.1172/JCl106540

16. Gaudry S, Verney C, Hajage D et al (2018) Hypothesis: early renal replacement therapy increases mortality in critically ill patients with acute on chronic renal failure. A post hoc analysis of the AKIKI trial. Intensive Care Med 44:1360-1361. https://doi.org/10.1007/s00134-018-5210-0

17. Zhang Z, Zhu C, Mo L, Hong Y (2018) Effectiveness of sodium bicarbonate infusion on mortality in septic patients with metabolic acidosis. Intensive Care Med 44:1888-1895. https://doi.org/10.1007/s00134-018-5379-2 